\title{
SANKSI HUKUM TERHADAP ANGGOTA KEPOLISIAN YANG MELAKUKAN PUNGUTAN LIAR
}

\author{
I Putu Gede Budihartawan, I Ketut Sukadana, I Nyoman Gede Sugiartha \\ Fakultas Hukum Universitas Warmadewa, Denpasar-Bali, Indonesia
}

\begin{abstract}
Abstrak
Pungutan liar yang umum dikenal dengan istilah pungli pada umumnya dilakukan oleh oknum pegawai dari suatu instansi bahkan oleh oknum petugas, tak terkecuali oknum aparat kepolisian. Aparat polisi yang bertugas mengayomi dan melindungi masyarakat seharusnya tidak melakukan perbuatan pungutan liar tersebut. Penyimpangan yang dilakukan anggota kepolisian ini menimbulkan masalah dan keresahan di tengah masyarakat. Berdasarkan latar belakang tersebut, penelitian ini dilakukan dengan tujuan mendeskripsikan bagaimana pengaturan larangan pungutan liar terhadap anggota kepolisian Republik Indonesia dan bagaimana sanksi Hukum Terhadap Anggota Kepolisian yang melakukan pungutan liar. Metode penelitian yang digunakan dalam penelitian ini adalah metode normatif. Dalam penelitian ini digunakan pendekatan perundang-undangan dan pendekatan konseptual. Larangan Pungutan Liar diatur pada pasal 6 huruf W Peraturan Pemerintah No.2 tahun 2003. Sanksi Hukum terhadap anggota kepolisian yang melakukan pungutan liar dikenakan ketentuan pasal 368, 378,423 KUHP. Pengaturan larangan dan sanksi terhadap pungutan liar harus lebih dipertegas agar oknum-oknum yang tidak bertanggung jawab tidak menimbulkan keresahan di tengah masyarakat.
\end{abstract}

Kata Kunci: Anggota Kepolisian; Pungutan Liar; Sanksi Hukum

\begin{abstract}
Illegal levies commonly known as extortion are generally carried out by unscrupulous employees from an agency and even by unscrupulous officers, including police officers. The police officers who are tasked with protecting and protecting the public should not commit such illegal payments. This deviation committed by members of the police caused problems and unrest in the community. Based on this background, this research was conducted with the aim of describing how the regulation prohibits illegal levies on members of the Indonesian police force and how the legal sanctions against members of the police who carry out illegal levies. The research method used in this study was the normative method. In this study a statutory and conceptual approach was used. Prohibition of Illegal Levies is regulated in article 6 letter W of Government Regulation No.2 of 2003. Legal sanctions against members of the police who carry illegal levies are subject to the provisions of articles 368, 378, 423 of the Criminal Code. The regulation of prohibitions and sanctions against illegal levies must be emphasized so that irresponsible persons do not cause unrest in the community.
\end{abstract}

Keywords: Police Members; Illegal Levies; Legal Sanctions

\section{PENDAhULUAN}

Kehidupan dan aktivitas manusia pada intinya mengandung beragam hal yang memperlihatkan sifat dasar kehidupan itu sendiri. Sifat dasar yang dimaksud di sini adalah sifat tidak kekal yang senantiasa mengiringi jalannya hidup dan aktivitas manusia secara umum. Sifat tidak kekal yang dimaksudkan selalu mencakup dan menemani manusia, baik sebagai individu, atau dalam bagian kelompok masyarakat dalam melakukan kegiatan mereka. Tentunya semua kegiatan ini tidak terlepas dari norma hukum yang berlaku di masyarakat (Christiani, 2016; Winarno, 2015). Tentunya agar efektivitas dari norma hukum yang berlaku dapat berlaku dengan maksimal diperlukan pengawas yang disebut sebagai penegak hukum (Arliman S, 2019; Sagama, 2016; Sibuea, 2016).

Di negara hukum seperti Indonesia ini tentunya diperlukan penegak hukum agar maksimalnya efektvitas norma hukum yang berlaku. Tapi tak bisa dipungkiri bahwa penegakan hukum di Indonesia belum terlaksana dengan efektif (Arliman S, 2019; Sanyoto, 2008). Hal ini tidak terlepas karena kurangnya tingkat kesadaran masyarakat, kurangnya aparat penegak hukum maupun tinginya kesempatan dalam melanggar aturan yang ada. Aparat penegak hukum mempuyai peranan sebagai 
jembatan dengan masyarakat agar dapat dikaji sejauh manakah aturan ini diterapkan. Penyimpangan dari aturan hukum ini bisa menimbulkan keterpurukan keberlakuan hukum yang ada dan berakibat tidak baik pada bidang hidup lainnya, khususnya bidang ekonomi bangsa.

Polisi sebagai struktur dari penegak hukum adalah aparat hukum yang memiliki kedekatan dengan masyarakat. Sebagai anggota aparat pemerintah dari Kepolisian Nasional dalam menjalankan tugasnya dilengkapi dengan serangkaian peraturan yang memberinya kewenangan, tetapi juga diberikan pembatasan untuk melakukannya. Selain dilengkapi dengan berbagai alat dalam bentuk legislasi, Kepolisian juga memiliki sejumlah kebijaksanaan Polisi dalam menjalankan tugasnya (Nugraha, 2018; Raharjo \& Angkasa, 2011).

Kepolisian Negara Republik Indonesia merupakan salah satu penegak hukum yang memiliki kewajiban (Danendra, 2012):

1. Menjaga agar ketertiban masyarakat terpelihara dengan aman

2. Melakukan penegakan hukum dan melindungi serta memberi pelayanan pada masyarakat

Pemberian hukuman kepada anggota polri yang melanggar disiplin kode etik berdasarkan keputusan sidang disiplin ataupun sidang kode etik belum bisa mengikat karena pemberian hukuman dilakukan oleh atasan dari anggota tersebut yang menyebabkan putusan sidang hanya bersifat berupa rekomendasi yang didasari kenyataan hukum yang muncul di dalam sidang. Tugas tersebut dilakukan oleh Propam yang bertugas melakukan pembinaan dan penyelengaraan terhadap fungsi dan tanggung jawab profesi serta memberikan pengalaman di lingkungan Polri dan menegakkan kedisiplinan di wilayah polri serta melayani rakyat yang mau melakukan pengaduan berkaitan ditemukan tindakan yang tidak sesuai diperbuat anggota/ PNS Polri (Sadjijono, 2008).

Pungli pada umumnya dilakukan oleh oknum pegawai dari suatu instansi bahkan oleh oknum petugas, tak terkecuali oknum aparat kepolisian. Polisi tidak seharusnya melakukan pungutan liar, karena polisi bekerja untuk mengayomi dan melindungi maysarakat. Kerugian akan dialami oleh masyarakat apabila oknum hukum melakukan pungutan liar dan pungutan liar tidak dibenarkan dalam hukum. Ini seharusnya tidak diizinkan untuk berlanjut tanpa solusi hukum. Oleh karena itu, setiap tindak pidana yang dilakukan oleh siapapun harus ditangani dan mengesampingkan status sosial, walaupun orang yang melakukannya adalah aparat hukum itu sendiri (Arliman S, 2019). Perbuatan seperti itu harus dihentikan dan harus diselesaikan dengan tuntas. Oleh sebab itu, siapapun yang melakukan perbuatan pidana walaupun penegak hukum itu sendiri harus dikenakan sanksi yang setimpal.

Berdasarkan latar belakang yang diuraikan di atas, penelitian ini dilakukan dengan tujuan menggambarkan bagaimana pengaturan tentang larangan pungutan liar terhadap anggota kepolisian Republik Indonesia, dan bagaimana sanksi hukum terhadap anggota kepolisian yang melakukan pungutan liar.

\section{METODE PENELITIAN}

Penelitian ini didesain dengan menggunakan pendekatan penelitian hukum normatif karena adanya kekaburan norma dalam latar belakang masalah penelitian ini. Pendekatan masalah yang dipergunakan ialah pendekatan Perundang-undangan (statute approach). Bahan hukum primer dikumpulkan dengan teknik dokumentasi dan bahan hukum sekunder dikumpulkan dengan teknik pencatatan dari bahanbahan hukum kepustakaan yang berhubungan sanksi hukum terhadap anggota kepolisian yang melakukan pungutan liar. Analisis bahan hukum menggunakan teknik interpretasi sistematis yang selanjutnya dituangkan secara deskriptif.

\section{HASIL DAN PEMBAHASAN}

1. Pengaturan tentang Larangan Pungutan Liar terhadap Anggota Kepolisian Republik Indonesia Penegak hukum adalah petugas dari badan-badan yang kompeten dalam menangani masalah keadilan yang tugasnya menyelesaikan konflik atau kasus hukum. Kesadaran hukum akan dapat tercipta jika orang menyadari adanya hukum dan tidak merugikan orang lain. Satjipto mengatakan bahwa esensi dari penegakan hukum adalah proses mengubah keinginan dan gagasan hukum menjadi kenyataan. Kehendak hukum adalah legislatif. Kepastian hukum dan manfaat sosial dirumuskan dalam aturan hukum dalam bentuk gagasan dan konsep tentang keadilan (Rahardjo, 2001). 
Tegaknya hukum di Indonesia sangat erat kaitannya dengan pejabat penegak hukum. Menurut perundangan yang berlaku, yang termasuk aparat penegak hukum antara lain (Kitab Undang-Undang Hukum Acara Pidana):

1. Penyelidik yaitu polisi atau PNS yang memiliki kewenangan tertentu berdasar undang-undang untuk melaksanakan penyelidikan.

2. Jaksa ialah pejabat yang bertugas melakukan penuntutan umum dan menjalankan putusan pengadilan yang sudah berkekuatan hukum.

3. Penuntut umum ialah jaksa yang melakukan kewenangan menurut undang- undang menjalankan penuntutan dan penetapan kehakiman.

4. Hakim adalah pejabat peradilan dengan wewenang memberikan keadilan pada masyarakat.

5. Penasihat hukum yaitu orang yang mempunyai kewenangan untuk memberikan bantuan hukum berdasarkan pada perundangan yang berlaku.

Karena itu, penegakan hukum pada dasarnya adalah proses mewujudnyatakan gagasan. Penegakan hukum adalah proses melaksanakan upaya normatif hukum atau fungsi aktual sebagai pedoman untuk lalu lintas dan kaitan hukum dalam kehidupan sosial dan nasional. Terdapat dua tipe model penegakan hukum, yaitu (Dellyana, 1988):

1. Ditinjau dari sudut subjeknya:

a. Dalam arti luas, proses penegakan hukum mencakup semua badan hukum dalam hubungan hukum apa pun. Siapa pun yang menegakkan aturan normatif, melakukan sesuatu berdasarkan norma aturan hukum, atau tidak melakukan apa pun berarti menegakkan atau menegakkan aturan hukum.

b. Dalam arti sempit, lembaga penegak hukum didefinisikan sebagai langkah menegakan hukum khusus untuk memberikan kepastian bahwa berjalan hukum seusai dengan peraturan yang berlaku.

2. Dilihat dari sudut objeknya, yaitu dari segi hukumnya:

a. Secara garis besar, lembaga penegak hukum yang memasukkan nilai-nilai keadilan, termasuk aturan formal dan nilai-nilai keadilan yang ada di masyarakat.

b. Secara khusus, lembaga penegak hukum hanya melibatkan penegakan hukum yang formal secara tertulis.

Hukum dan peraturan Indonesia tidak mendefinisikan kejahatan. Definisi kejahatan yang dipahami sejauh ini adalah penciptaan teoritis para profesional hukum. Para profesional hukum pidana umumnya masih memasukkan kesalahan sebagai bagian dari definisi kegiatan kriminal. Hal yang sama berlaku untuk apa yang didefinisikan oleh Simons dan Van Hamel. Pandangan dua ahli hukum pidana Belanda telah mewarnai pandangan ahli hukum pidana Belanda dan Indonesia sampai saat ini (Huda, 2011).

Menurut Simon strafbaarfeit adalah perilaku yang terancam kejahatan, bertentangan dengan hukum, dan terkait dengan kesalahan yang dilakukan oleh orang-orang yang mampu bertanggung jawab (Hamzah, 2008). Sementara itu, Van Hamel mengatakan bahwa strafbaatfeit adalah perilaku orang yang dirumuskan dalam hukum, bertentangan dengan hukum, layak dihukum dan dilakukan dengan kesalahan. Keduanya masih memasukkan kesalahan dalam definisi kejahatan. Terkait dengan kesalahan atau dilakukan dengan kesalahan adalah ungkapan yang memberi tanda, bahwa baginya suatu perbuatan merupakan tindak pidana apabila di dalamnya juga dirumuskan tentang suatu kesalahan.

Kejahatan adalah tingkah laku manusia yang dirumuskan dalam hukum, tidak sesuai dengan hukum, yang wajar dihukum dan dilakukan karena kesalahan. Seseorang yang melakukan kejahatan harus mempertanggungjawabkan kesalahan yang diperbuat jika ia mempunyai kesalahan. Seseorang memiliki kesalahan pada saat bertindak yang ditinjau berdasar sudut pandang masyarakat, memperlihatkan pandangan normatif dari kesalahan yang dilakukan (Hamzah, 2001).

Pungutan liar adalah merupakan tindakan aparat yang menyalahi wewenang yang diberikan bertujuan untuk mempermudah kegiatan untuk kepentingan sendiri dari pihak yang membayar pungutan. Dalam kasus pungli terdapat dua pihak yang terlibat, antara lain pengguna jasa dan oknum petugas yang sering berhadapan langsung untuk melaksanakan kegiatan tersembunyi maupun yang terang-terangan. Kegiatan pungutan liar dilaksanakan di lapangan yang dilakukan sesingkat mungkin dan transaksi berbentuk uang (Wibawa, Fauzy, \& Habibah, 2013). 
Masyarakat mengenal pungli dengan banyak istilah, antara lain uang sogok, uang pelicin, uang semir, dan sebagainya (Soedjono, 1983). Menurut dokumen PBB mengenai langkah memberantas korupsi, pungli adalah pemungutan yang tidak sah, meminta dana menerima pembayaran, yang dilakuan oleh aparat secara tidak wajar dari pihak swasta maupun pengusaha transnasional untuk melakukan kegaitan usaha transnasional.

Berikut bunyi Pasal di dalam KUHP yang dapat menjelaskan mengenai perbuatan pungutan liar antara lain:

a. Pasal 12 huruf e

"Pegawai negeri atau penyelenggara negara yang dengan maksud menguntungkan diri sendiri atau orang lain secara melawan hukum atau dengan menyalahgunakan kekuasaannya, memaksa seseorang memberikan sesuatu, membayar, atau menerima pembayaran dengan potongan, atau untuk mengerjakan sesuatu bagi dirinya sendiri."

b. Pasal 12 huruf $\mathrm{f}$

"Pegawai negeri atau penyelenggara negara yang pada waktu menjalankan tugas, meminta, menerima, atau memotong pembayaran kepada pegawai negeri atau penyelenggara negara yang lain atau kepada kas umum, seolah-olah pegawai negeri atau penyelenggara negara yang lain atau kas umum tersebut mempunyai utang kepadanya, padahal diketahui bahwa hal tersebut bukan merupakan utang."

\section{Sanksi Hukum terhadap Anggota Kepolisian yang Melakukan Pungutan Liar}

Belum diaturnya secara jelas tindak pidana pungutan liar dalam KUHP, maka pungli dapat diklasifikasikan sebagai perbuatan tindak pidana yang hampir sejenis atau penggabungan dari tiga tindak pidana yang dijelaskan maupun yang diatur di dalam KUHP yaitu sebagai berikut:

1. Tindak pidana pemerasaan

Dalam kejahatan pemerasan, di mana ada unsur tindakan yang ingin memperoleh keuntungan untuk diri sendiri atau orang lain secara tidak sah diikuti serangkaian ancaman, sehingga orang lain dapat memberikan barang atau sesuatu kepadanya. Di dalam tindak pidana pemerasan, dimana terdapat unsur-unsur perbuatan yang ingin menguntungkan diri sendiri atau orang lain secara melawan hukum dengan rangkaian ancaman agar orang lain dapat menyerahkan barang atau sesuatu kepadanya.

2. Tindak pidana penipuan

Penipuan dan pemerasan adalah tindakan kriminal di mana ada unsur-unsur yang sama dan saling terkait, antara lain, untuk memberi untung bagi diri sendiri atau orang lain secara tidak sah dengan serangkaian kebohongan untuk atau bagi orang lain untuk menyerahkan barang kepada mereka.

3. Tindak pidana kejahatan jabatan

Kejahatan jabatan dan pungutan liar adalah tindak pidana yang mana sangat berkaitan karena menyalahgunakan wewenang atau kekuasaannya, atau memaksa orang lain demi keuntungannya pribadi.

KUHP tidak mengatur secara pasti tentang kejahatan pungutan liar, tetapi pungutan liar hampir sama artinya dengan tindakan pidana kejahatan jabatan, pemerasan dan kecurangan yang ditentukan KUHP. Huruf $\mathrm{W}$ pada pasal 6 penjelasan atas peraturan perundangan tentang Peraturan Disiplin Anggota Kepolisian Negara Republik Indonesia dapat dijadikan sebagai aturan larangan pungutan liar bagi Anggota Kepolisian Negara Republik Indonesia.

Pungutan liar merupakan kejahatan yang tidak asing bagi masyarakat. Meskipun dalam KUHP tidak ditemukan mengenai tindak pidana pemerasan atau tuduhan ilegal. Tetapi secara implisit terdapat pada perumusan korupsi di beberapa pasal termasuk Pasal 423 KUHP sebagaimana dimaksud dalam pasal 12 UU No. 31 tahun 1999 sebagai tindak pidana korupsi, dimana selanjutnya dirumuskan kembali dalam Undang-Undang Nomor 20 Tahun 2001 tentang korupsi.

Dari uraian di atas dapat diketahui bahwa unsur-unsur pungutan liar mengandung unsur obyektif dan unsur subyektif, termasuk Lainnya ialah:

1. Unsur-unsur Objektif.

Unsur objektif menurut peraturan perndangan yang berlaku berkaitan dengan:

a. Pegawai negeri, atau penyelenggara Negara, atau pejabat; 
b. Menyalahgunakan kekuasaan;

c. Memaksa seseorang:

1) Memberikan sesuatu

2) Membayar

3) Menerima

4) Mengerjakan sesuatu bagi dirinya sendiri.

2. Unsur-Unsur Subjektif

Pada pungutan liar yang menjadi unsur-unsur objektif dalam hal ini adalah:

a. Menguntungkan diri sendiri atau orang lain;

b. Menguntungkan secara melawan hukum.

Menurut KPK, pungli juga termasuk gratifikasi yang diatur dalam Undang-Undang Tentang Tindak Pidana Korupsi. Oleh karena itu oknum kepolisian yang melakukan pungutan liar dapat dijerat dengan aturan perundang-undangan tersebut.

KUHP:

Penjelasan Hukuman Pidana penjara jika melanggar perbuatan pidana tersebut diatur pada

1. BAB XXIII KUHP pasal 368 tentang Pemerasan dan Pengancaman yang berbunyi:

"Barang siapa yang bermaksud menguntungkan diri sendiri atau orang lain secara melawan hukum, memaksa seseorang dengan kekerasan untuk memberikan orang itu atau orang lain, atau supaya membuat utang maupun menghapus piutang, diancam karena pemerasan, dengan hukuman pidana penjara paling lama sembilan tahun".

2. BAB XXV KUHP pasal 378 tentang Perbuatan Curang yang berbunyi:

"Barang siapa dengan maksud untuk menguntungkan diri sendiri atau orang lain secara melawan hukum, dengan memakai nama palsu atau martabat palsu, dengan tipu muslihat, ataupun rangkaian kebohongan, menggerakan orang lain untuk menyerahkan barang sesuatu kepadanya, atau supaya memberi uang ataupun menghapuskan piutang, diancam karena penipuan dengan pidana penjara paling lama empat tahun".

3. BAB XXVIII pasal 423 tentang Kejahatan Jabatan yang berbunyi:

"Seorang pejabat dengan maksud menguntungkan diri sendiri atau orang lain secara melawan hukum, dengan menyalahgunakan kekuasaannya, memaksa seseorang untuk memberikan sesuatu, untuk membayar atau menerima pembayaran dengan potongan, atau untuk mengerjakan sesuatu bagi dirinya sendiri, diancam dengan pidana penjara paling lama enam tahun".

\section{SIMPULAN DAN SARAN}

\section{Simpulan}

Berdasarkan hasil analisis data, ada beberapa simpulan yang dapat dibuat, yaitu: pertama, pengaturan larangan pungutan liar di Indonesia diatur pada pasal 6 huruf W Peraturan Pemerintah Republik Indonesia Nomor 2 Tahun 2003 tentang Pengaturan Disiplin bagi Anggota Kepolisian Negara Republik Indonesia. Jadi, aparat kepolisian sudah diikat secara hukum untuk tidak melakukan tindakan pengutan liar. Kedua, sanksi hukum terhadap anggota kepolisian yang melakukan pungutan liar telah diatur dalam KUHP sesuai dengan ketentuan pasal 368, 378, dan 423 yang mengatur tentang pemerasan, perbuatan curang, dan kejahatan jabatan. Oleh karena itu, anggota kepolisian tidak terlepas dari jeratan hukum jika melakukan perbuat pungutan liar.

\section{Saran}

Berdasarkan hasil dan simpulan penelitian ini, ada beberapa saran yang perlu disampaikan kepada beberapa pihak, yaitu: pertama, bagi pihak penegak hukum untuk menindak tegas oknum-oknum kepolisian yang melakukan tindakan pengutan liar serta menimbulkan keresahan di tengah masyarakat. Kedua, bagi masyarakat untuk melaporkan kepada pihak penegak hukum lain jika terdapat oknum kepolisian yang melakukan tindakan pungutan liar.

\section{DAFTAR PUSTAKA}

Arliman S, L. (2019). Mewujudkan Penegakan Hukum yang Baik di Negara Hukum Indonesia. Dialogia Iuridica: Jurnal Hukum Bisnis Dan Investasi, 11(1), 1-20. https://doi.org/10.28932/di.v11i1.1831 
Christiani, W. (2016). Hukum sebagai Norma Sosial Memiliki Sifat Mewajibkan. ADIL: Jurnal Hukum, 4(1), 151-167. Retrieved from https://media.neliti.com/media/publications/53701-ID-none.pdf. Diakses 12 Oktober 2018

Danendra, I. B. K. (2012). Kedudukan dan Fungsi Kepolisian dalam Struktur Organisasi Negara Republik Indonesia. Lex Crimen, 1(4). Retrieved from https://media.neliti.com/media/publications/3161-ID-kedudukan-dan-fungsi-kepolisian-dalamstruktur-organisasi-negara-republik-indone.pdf

Dellyana, S. (1988). Konsep Penegakan Hukum. Yogyakarta: Liberty.

Hamzah, A. (2001). Bunga Rampai Hukum Pidana dan Acara Pidana. Jakarta: Ghalia Indonesia.

Hamzah, A. (2008). Asas-Asas Hukum Pidana. Jakarta: Rineka Cipta.

Huda, C. (2011). Dari Tiada Pidana Tanpa Kesalahan Menuju Kepada Tiada Pertanggungjawaban Pidana Tanpa Kesalahan:Tinjauan Kritis Terhadap Teori Pemisahan Tindak Pidana dan Pertanggungjawaban Pidana. Jakarta: Kencana.

Nugraha, S. (2018). Hubungan antara Kepolisian dan Pemerintah Daerah dalam Menegakkan Ketertiban Masyarakat. Morality: Jurnal Ilmu Hukum, 4(1), 1-20. Retrieved from http://jurnal.upgriplk.ac.id/index.php/morality/article/view/63/49

Rahardjo, S. (2001). Masalah Penegakan Hukum: Suatu Tinjauan Sosiologis. Bandung: Sinar Baru.

Raharjo, A., \& Angkasa. (2011). Profesionalisme Polisi dalam Penegakan Hukum. Jurnal Dinamika Hukum, 11(3), 389-401. Retrieved from http://dinamikahukum.fh.unsoed.ac.id/index.php/JDH/article/download/167/115

Sadjijono. (2008). Etika Profesi Hukum: Suatu Telah Filosofis terhadap Konsep dan Implementasi Kode Etik Profesi POLRI. Yogyakarta: Laksbang Mediatama.

Sagama, S. (2016). Analisis Konsep Keadilan, Kepastian Hukum dan Kemanfaatan dalam Pengelolaan Lingkungan. Mazahib, 15(1), 20-41. https://doi.org/10.21093/mj.v15i1.590

Sanyoto. (2008). Penegakan Hukum di Indonesia. Jurnal Dinamika Hukum, 8(3), 199-204. Retrieved from http://www.dinamikahukum.fh.unsoed.ac.id/index.php/JDH/article/download/74/226

Sibuea, H. Y. P. (2016). Penegakan Hukum Pengaturan Minuman Beralkohol. Negara Hukum, 7(1), 127-143. Retrieved from file:///C:/Users/Sinta/Downloads/926-1900-1-SM.pdf

Soedjono, D. (1983). Pungli Analisa Hukum dan Kriminologi. Bandung: CV Sinar Baru.

Wibawa, S., Fauzy, A., \& Habibah, D. A. (2013). Efektivitas Pengawasan Pungutan Liar di Jembatan Timbang. Jurnal Ilmu Administrasi Negara, 12(2), 74-85. Retrieved from http://download.portalgaruda.org/article.php?article=129520\&val=2287

Winarno, R. (2015). Arti Penting Nilai-Nilai dan Norma Hukum dalam Berpolitik Praktis. Perspektif, 20(2), 79-89. https://doi.org/10.30742/perspektif.v20i2.143

Kitab Undang - Undang Hukum Pidana (KUHP)

Kitab Undang-Undanng Hukum Acara Pidana

UU No. 2 Tahun 2002 tentang Kepolisian Negara Republik Indonesia

PP No. 2 Tahun 2003 tentang Peraturan Disiplin Bagi Anggota Polri

PP No. 3 Tahun 2003 tentang Pelaksanaan Teknis Institusional Peradilan Umum Bagi Anggota Polri Perpres No. 87 Tahun 2016 tentang Satuan Tugas Sapu Bersih Pungutan Liar 